\title{
Self-Actualization Learning for College Students Using Siddhartha Story
}

\author{
Ellychristina D.Hutubessy, Ezmir, Sabarti Akhdiyah \\ \{ ellychristina@unj.ac.id ${ }^{1}$,emzir.unj@unj.ac.id ${ }^{2}$, sabartiakhadiah@yahoo.com ${ }^{3}$ \} \\ Language Education, Postgraduate of State University Jakarta, Jakarta, Indonesia ${ }^{1,2,3}$
}

\begin{abstract}
The purpose of this study is to find the process of self-actualization learning for college using literary text 'Siddhartha story'. This novel was written in 1922 represents human anxiety in achieving self-actualization. This study used a descriptive qualitative method. The results showed that the process of self-actualization of Siddhartha figures according to Carl Rogers typical characteristic theory tends to start feeling free want to feel dissatisfied. Siddhartha has 3 phases of life namely the phases of the spiritual life, the phase of earthly life and the phase of the wise life. From this story, some students can build their self-actualization that impact to build the character value as in the 2013 curriculum.
\end{abstract}

Keywords: Self-actualization, Learning, Novel, Siddhartha

\section{Introduction}

The learning process in Indonesia is oriented towards character building, the focus of attention is on how to foster learners' awareness about their potential. To accommodate this purpose, the government has formulated policies in the framework of building national character. In the National Policy for the Development of Nation Character in 2010-2025, it was emphasized that the character is the result of four parts integration, namely the process of heart, think, body, and feeling and intention [1].

The heart is closely related to one's feelings and beliefs. Think is about the reasoning process to find and use knowledge critically, creatively, and innovatively. Body is related to the process of perception, readiness, imitation, manipulation, and the creation of new activities accompanied by sportsmanship. Feelings and intentions related to the will and creativity reflected in caring, imaging, and creating newness [2] Through these 4 character building parts, every learner is expected to be a psychologically healthy human being and aware of his own abilities. After that, the learner can truly actualize himself with every human value that exists in his life.

The results of research conducted by Baitela et al, it was proven that the potential of selfactualization is a process that continues continuously and may not be in the form of positive action [3]. This means that the attitude or human personality can show good potential on the one hand, but on the other side and at the same time it also acts not in accordance with the norms imposed in society. For this reason, humans must be able to act and determine attitudes or actions in their lives, without having to be overshadowed by the good conditions in the past or the circumstances that will occur in the future. 
In education, students learned about facts and ideas that were static. In accordance with the circumstances at that time the world was going through a process of seeking to change and what is obtained at school is seen as sufficient to meet the demands of the times at that time. Therefore, the demand for a teacher is enough to convey the learning material according to the applicable book or curriculum.

At this time, the change is a major fact of life. Science and Technology are always moving forward. What has been learned in the past cannot equip people to live and function both now and in the future. Thus, what is needed is people who are able to learn in an environment that is changing and will continue to change. In order that the tendency of Rogers's self-actualization concept can be realized in the life of the learner, Pescitelli confirms that learners need to be aware that every living being has the potential that can be developed optimally. This potential is needed to deal with the events that occur and act to accept the truth about what has happened [4].

The process of self-actualization building can use literary work. It is one of the medium for moral and other value learning in the college. Because all people like literary work. Lestari wrote that literary works can make humans interact with themselves, others, nature and the environment and their creator [5]. Thus through learning and understanding of literature, each student can learn the values of self-actualization. One example of literary work that can be used is the Siddhartha romance.

Siddhartha is one of Hermann Hesse's works, a German-born author (1877), who won a Nobel in the field of literature in 1946. His famous works are Steppenwolf, Siddhartha, and The Glass Bead Game. Even Siddhartha's story has been translated into various languages including Indonesian. In addition, Siddhartha's story has also been produced as a feature film [5]. From the research conducted by Dieu, it is known that the romance of Siddhartha describes the life journey of a young man from the family of Brahmins who had the same name as Gotama, namely Siddhartha. In this romance, Siddhartha tries to achieve the happiness of life through the 4 stages of life that are natural [6]. It is a process of selfactualization. This concept has different for human. Maslow stated that self-actualization is one of the universal needs of individuals. The attainment of self-actualization is seen as hierarchical, namely is new individuals will achieve self-actualization when individuals have satisfied the four lower-level needs of physiological needs, security needs, need for belonging and a sense of love, and the need for self-esteem [7].

Whereas the main concept of Rogers's theory of personality is self-approach emphasizes that one must rely on his own experience of the world [8]. Therefore, individuals are free to actualize themselves to develop their potential [9]. This statement illustrates that Rogers emphasized his theory of individual concepts about himself and the characteristics considered to be part of himself. Therefore, the final process of self-actualization according to Rogers's concept leads to the achievement of self-determination as much as possible. The core of the human self has the ability to determine its own destiny, even the deepest essence of humans is its nature which aims to be trusted and pursue self-perfection (purposive, trustworthy, selfperfecting) [10]. After the process of self-actualization takes place, the individual can go to the final goal of being a fully functioning person.

People who act self-actualize according to Rogers are people who succeed in experiencing the process of heading towards self-actualization. The process of selfactualization takes place towards the ultimate goal of being a fully functioning person, with the characteristics described below [11]; 


\subsection{Openness to experience}

Openness to experience refers to someone who is free to experience all feelings and attitudes. No one has to fight because no one is threatening. So, openness to experience is the opposite of a defensive attitude. Defensive is the organism's response to experiences that are perceived as threatening or not in accordance with the self-image. In this situation, individuals have anticipated the threatening experience.

\subsection{Being in Existential life}

A fully functioning person always lived in every moment of life. Every experience is felt fresh and new. Something experienced as before has never existed.

\subsection{The existence of self-confidence in the organism}

An individual who experiences an increase in his own organism means that the individual has confidence in himself when he chooses the direction of the behaviour he must take.

\subsection{Have Free Feelings}

Psychologically healthy, people can make choices without coercion or hindrance between alternative thoughts and actions.

\subsection{Always Creative}

Openness to experience and trust in their own organisms will encourage a person to have created with the characteristics of spontaneous behaviour, not defensive, changing, growing, and developing in response to the various life stimuli around him. Rogers believes that fully functioning people are better able to adjust and endure traumatic changes.

To know the implementation of self-actualization from the students, the teacher can use literary work as the media of learning. The use of literature as a technique for teaching both basic language skills (i.e. reading, writing, listening and speaking) and language areas (i.e. vocabulary, grammar and pronunciation) is very popular within the field of foreign language learning and teaching nowadays [12]. Collie and Slater [13], there are four main reasons which lead a language teacher to use literature in the classroom. These are valuable authentic material, cultural enrichment, language enrichment and personal involvement. In addition to these four main reasons, universality, non-triviality, personal relevance, variety, interest, economy and suggestive power and ambiguity are some other factors requiring the use of literature as a powerful resource in the classroom context. When selecting the literary texts to be used in language classes, the language teacher should take needs, motivation, interests, cultural background and language level of the students.

Aside from the length of the work, there are some other important criteria that must be considered while choosing the text. Hill, points out the basic criteria to be kept in mind while choosing a literary text as follows: the needs and abilities of the students, the linguistic and stylistic level of the text, and the amount of background information required for a true appreciation of the material [14]. Lazar stated that literature should be used in the language classroom because of [15]: 
1. It is very motivating.

2. It is an authentic material.

3. It has a general educational value.

4. It is found in many syllabuses.

5. It helps students to understand another culture.

6. It is a stimulus for language acquisition.

7. It develops students' interpretative abilities.

8. Students enjoy it and it is fun.

9. It is highly valued and has a high status.

10. It expands students' language awareness.

11. It encourages students to talk about their opinions and feelings.

Similarly, McKay claims that one of the most important contributions of using literature for language teaching purposes is that "literature presents language in discourse", which will exemplify why a specific language form should be used and in this way, it will contribute to the development of students' language awareness. In addition to this benefit, she also mentions some other benefits such as fostering students' reading proficiency, promoting tolerance for cultural differences, and leading to more creative students in the language classroom [16].

Based on this explanation, this research explores and analyzes each of the selfactualization values of the main character 'Siddhartha' which is implemented in the learning process in the class. The formulation of the problem in this research as follows; how is the implementation of self-actualization learning from Siddhartha story in the class?

\section{Method}

\subsection{Methods and Procedure}

This study used a descriptive qualitative method. The qualitative descriptive research method is explained in a variety of general qualitative research resources. It views the phenomenon of interest [17]. The method was used to find and analyze 12 stories in Siddhartha novel.

\subsection{Participant of Research}

Participants in this study were the researchers themselves as people who made direct observations and analyzes of findings data

\subsection{The process of Collecting Data}

The data are taken from the utterance of Siddhartha character in the romance, observation in the class when the teacher implemented self-actualization learning in the class, and discussion to know students' perception of interpretation self-actualization value in the learning process. 


\subsection{The technique of Data Analysis}

In this study, the validity of the data used is credibility carried out by using theory and steps; 1) making persistent observation, 2) triangulating, and 3) expert checking and peer checking [18]. Diligent observation of the data is done by observing psychological phenomena about self-actualization inherent in the behavior of the main character in the novel Siddhartha. Observations are carried out continuously by reading romances repeatedly. This method is taken in order to find some aspects that are useful for strengthening research data.

Triangulation is used as a data validity checking technique that utilizes something other than data as a comparison to data. The triangulation of the theory in this study was conducted by examining the suitability between the psychological theory of self-actualization of Carl Rogers and the sentences that appear in the story.

Peer / expert examinations are conducted by discussing the findings of research on the concept of self-actualization found in the Siddhartha novel with psychologists. The exchange of ideas was also carried out with an expert in German language and literature.

\section{Finding And Discussion}

The whole story in this romance is arranged in three phases of Siddhartha's life with 12 stories, namely; 1) der Sohn des Brahmanen, 2) Bei den Samanas, 3) Gotama, 4) Erwachen, 5) Kamala, 6) Bei den Kindermenschen, 7) Sansara, 8) Am Flusse, 9) Der Fährmann, 10) Der Sohn, 11) .Om, 12) Govinda. The phase-in Siddhartha's story can be concluded through the table as follows [19]:

Table 1. Phases of Siddhartha's life

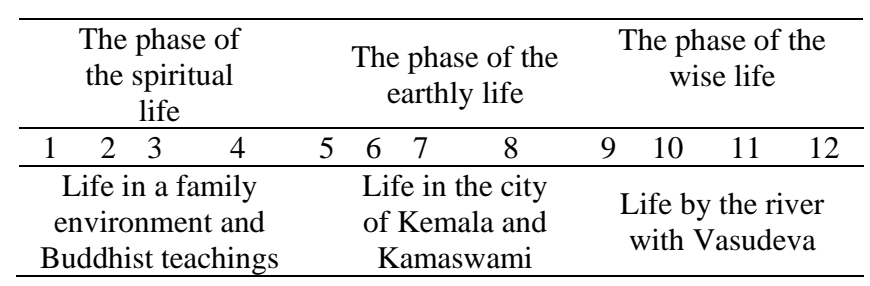

Note :

1) Der Sohn des Brahmanen (Brahmana's Child)

2) Bei den Samanas (With Samana)

3) Gotama (Gotama)

4) Erwachen (Awareness)

5) Kamala (Kamala)

6) Bei den Kindermenschen (With lay people)

7) Sansara(Samsara)

8) Am Flusse (On the side of the river)

9) Der Fährmann (The Boatman)

10) Der Sohn ( Boys)

11) $\mathrm{Om}(\mathrm{Om})$

12) Govinda (Govinda) 
From the findings of Siddhartha's phase of life in the table above, it can be taught to students related to the values of self-actualization in the learning process in the classroom. The following is a chart of Siddhartha's self-actualization interpretation that is implemented in the real life of students in the classroom.

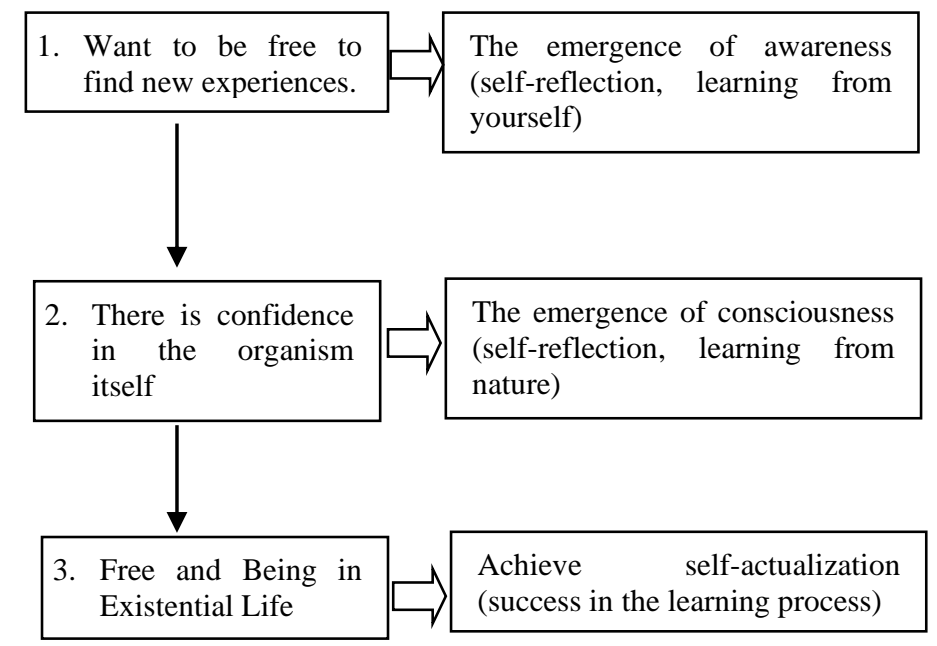

Fig. 1. Siddhartha's self-actualization interpretation

In the first phase, students can understand that they have the freedom to find new things through the learning process in the classroom and outside the classroom. For example, students can take part in various activities on campus and off campus that are able to provide new experiences, like as seminar, workshop, training, etc. In the second stage, students can communicate with everyone without discriminating on status or ethnicity but they still have the principles of life. So that, students can meet the need for wider learning. The third stage, the students always repeat their learning and comprehend the meaning of learning.

Three phases of Siddhartha's life can be grouped. The first is spiritual life phase. In this phase, the life of Siddhartha from childhood in the family of a Brahmin with the background of Hinduism and Thao arrived at the early phases of Siddhartha's life in seeking answers about the perfection of life. The four title stories describing the initial phases of this theme are der Sohn des Brahmanen, Bei den Samanas, Gotama and Erwachen.

The second phase is earthly life phase. The phase describes the life of Siddhartha who no longer focuses on religious teachings, but involves himself in earthly life that he has never learned or felt. In this theme, Siddhartha's relationship with the beautiful and beautiful prostitute is described. It taught Siddhartha all the pleasures of the world through love relations with Kemala, taking as much profit as possible through the business he did with Kamaswami. The four titles of stories that describe Siddhartha's earthly phase of life are Kamala, Bei den Kindermenschen, Sansara and Am Flusse.

The third phase is the wise life phase. The third phase tells the phases of Siddhartha's life after experiencing a downturn in worldly life. In the third phase, Siddhartha met with the boatman Vasudeva by the river and also met with Siddhartha's sons and the emergence of Siddhartha's self-consciousness and his reunion with his childhood friend, Govinda. Fourstory titles that illustrate the return of consciousness to the attainment of Siddhartha's selfactualization, namely der Fährmann, der Sohn, OM and Govinda.

Siddhartha's life phase has a value that is directly related to everyone's real life. In the present era, these values can function as part of the life-giving process that not only refers to 
relationships with God but also builds a relationship of life with nature or the environment. It relates to the character education in accordance with the 2013 curriculum, every student is given the opportunity to develop themselves according to their character. For this reason, every teacher needs to give attention to the process of self-actualization of each student. This is consistent with the results of research on the teacher conducted by Rawat [20]. Rogers stated self-actualization is a tendency to progress toward a level of maturity, independence or greater personal responsibility because each individual has the innate to actualize himself.

The process of self-actualization in individuals depends on the individual's personal experience and emotions, feelings and attitudes towards the experience. Therefore, in the process of character building, the individual as the object of learning is very instrumental in determining the nature and form of his actualization. Self is formed in relationships with other people, so that a healthy individual will assimilate new experiences, change their self-structure and continue to develop, becoming individuals who can accept and understand others. Individuals who are able to actualize themselves, believe in the power/strength they have, without feeling the need to master others (power over others). Thus, as the result of Rachmahana's research, what is needed now is Rogers learning principles that are intended to enable people to learn in an environment that is changing and will continue to change [21].

Self-actualization has variation concept. Like as in Du's study about Self-Actualization of Amir in The Kite Runner. The Kite Runner bears a typical theme of growth. Amir finally completed his self-salvation and became mature. After suffering from psychological torment, which raises him to a new height and makes him realize and correct the past mistakes, Amir enters a realm in the spirit of transcendence. The glory and darkness of human nature are two sides inside a person. Self-actualization is both the process of self discovery and the return of the bright side of human nature. A personal growth may represent all of ours. Just as the writer Hosseini describes: behind every dusty face has a soul, and determined to flick over ordinary Afghans face's dust, which will be displayed behind the "soul" to the world [22]. The process of self-actualization of Siddhartha and Amir shows the similarity the process of finding identity to deal with life. The process of suffering psychology has built every soul of the two main characters into a better human being. A process of someone being themselves and can reveal unique psychological potential and strive to achieve optimal self-growth and fully functioning person.

The positive contribution that can be given through the findings of this study for education, especially learning German language at universities in Indonesia based on the purpose of the curriculum is to provide opportunities for learners to recognize the types of literary works that can describe human life according to real life. Furthermore, the material of the Siddhartha romance text can be used as a medium for learning culture or culture (because in this story it is also related to religious and cultural life).

From the Siddhartha's life, there were several things that students could learn. Students as humans who grow in this millennia era need to know themselves, and motivations to do things. Students need to realize that life has meaning, even in the most depressing situations. The important thing that still needs to be an urge is to understand that the main purpose of life is to find the meaning of life itself. Like Siddhartha, everyone has the freedom to interpret what they want to do and experience. For this reason, students must be able to accept the reality of the situation. Then students are able to act to deal with obstacles that may arise towards development to a higher level.

The achievement of one's self-actualization is done by believing in oneself, and focusing on the teachings that are believed to lead to the peak of self-actualization itself. From the events of Siddhartha's life journey associated with psychology, illustrates that selfactualization is the single source of energy in human life. Therefore, anyone who is human, 
however condition if he already has the energy to achieve the full function of life, then man can experience self-actualization.

The process of a person's life to achieve self-actualization through this literary Psychology approach, can provide a positive contribution to every reader who wants to understand more about the psychiatric setting of a character that may be experienced by humans in real life. For this reason, the result of research is recommended to arouse the awareness of learners so that they can be psychologically healthy and aware of their own abilities. After that, the learner can truly actualize himself with every human value that exists in his life. At the same time, students can realize the goals of the government policy on the development of national character by realizing 4 basic education of the heart, think, body and taste and intention.

\section{Conclusion}

Siddhartha story has interest process of self-actualization. It teaches how to be themselves. Each can make a choice in life, and share life with others. We teach to take the action and have the creativity to deal with life and situations that change at any time. So that we can find perfection, respect life as a whole that is based on love, honesty and loyalty to the call of his heart, as the main view in this life. In Siddhartha story can be seen from 3 phases of life are named the phase of the spiritual life, the phase of the earthly life and the phase of the wise life.

From the story, students can be implemented the value of Siddhartha's self-actualization in the learning process. From the learning process of Siddhartha's story, students have understood how to develop an attitude of accepting the facts and challenges faced during the learning process. Students have had a fairly good level of critical thinking through the story so that almost all students in the class who received literary learning about Siddharta's story were able to deal with learning barriers, and behaviour change occurred towards better learning attitudes.

\section{References}

[1] P. R. Indonesia, Kebijakan Nasional Pembangunan Karakter Bangsa Tahun 2010-2025. Jakarta: Pusat Kurikulum Balitbang Kemdiknas, 2010.

[2] Ibid, "No Title."

[3] E. a. Beitela, Mark, "Humanistic experience and psychodynamic understanding: empirical associations among facets of self-actualization and psychological mindedness," 2015. [Online]. Available: https://www.tandfonline.com/doi/full/ 10.1080/14779757.2014.981653 .

[4] D. Pescitelli, "An Analysis of Carl Rogers' Theory of Personality," 1996.

[5] C. B. Lestari, "Self-actualization of The Main Character Hujan Novel by Tere Liye A Review of Psychology Abraham Maslow," BAHTERA J. Pendidik. Bhs. dan Sastra, vol. 17, p. 75, 2018.

[6] L. P. Dieu, "Weltperspektiven in verschiedenen Phasen des Lebens der Hauptfigur des WerksSiddhartha Vietnam: Universität Hanoi," 2015. [Online]. Available: https://www.academia.edu/12652579/Die_Weltperspektiven_und_Philosophie_von_Hermann_Hesses _philosophischem_Roman_Siddhartha_eine_indische_Dichtung_.

[7] S. Duane, Psikologi Pertumbuhan: Model - Model Kepribadian Sehat. Yogyakarta: Kanisius, 1991.

[8] S. McLeod and C. Rogers, "Self Actualization," 2014. [Online]. Available: www.simplypsychology.org/carl-rogers.html.

[9] S. Duane, "No Title," op.cit, pp. 51-54.

[10] A. Nik and M. Tekke, "Rediscovering Rogers's Self Theory and Personality," J. Educ. Heal. Community Psychol., vol. 4, p. 31, 2015. 
[11] L. A. Hjelle and D. J.Ziegler, Personality Theories, Basic Assumptions, Research, and Application, Second Edi. Auckland: Mc Graw-Hill International Editions, Psychology Series, 1988.

[12] M. Hişmanoğlu, "Teaching English Through Literature," J. Lang. Linguist. Stud., vol. 1, p. 54, 2005.

[13] J. Collie and S. Slater, Literature in the Language Classroom: A Resource Book of Ideas and Activities. Cambridge: CUP, 1990.

[14] J. Hill, Using literature in language teaching. London: Mcmillan, 1994.

[15] G. Lazar, Literature and language teaching. Cambridge, UK: Cambridge University Press, 1993.

[16] S. McKay, "Literature in the ESL classroom," TESOL Q., vol. 16 (4), pp. 529-536, 1982.

[17] R. R. Parse, Qualitative Inquiry: The Path Sciencing. New York: NLN, 2001.

[18] Y. S. Lincoln and C. Egon G, Naturalistic Inquiry. Beverly Hills: Sage publication, 1985.

[19] The result of adaptation from Maria Felicitas Herforth, Erläuterungen und Materialien Interpretation zu Hermann Hesse ,Siddhartha. Hollfeld: Bange Verlag, 2008.

[20] A. Rawat, "A Study of the Self-Actualization of B.Ed Teacher Trainees," Int. Multidiscip. Res. J., vol. 3, no. 3, p. 78, 2015.

[21] R. S. Rachmahana, "Psikologi Humanistik dan Aplikasinya dalam Pendidikan," El Tarbawi J. Pendidik. Islam, vol. 1, p. 103, 2008.

[22] J. Du, "A Journey of Self-Actualization of Amir in The Kite Runner Juan,” English Lang. Lit. Stud., vol. 7, 2017. 